\title{
Evaluating the infiltration capacity of degraded vs. rehabilitated urban greenspaces: Lessons learnt from a real-world Italian case study
}

\author{
Andrea Galli ${ }^{a}{ }$, Cosimo Peruzzi $^{\mathrm{a}}$, Ludovica Beltrame ${ }^{\mathrm{a}}$, Alessio Cislaghi ${ }^{\mathrm{a}, \mathrm{b}}$, Daniele Masseroni ${ }^{\mathrm{a}, *}$ \\ a Department of Agricultural and Environmental Sciences (DiSAA), University of Milan, Via Celoria 2, 20133 Milan, Italy \\ ${ }^{\mathrm{b}}$ Centre of Applied Studies for the Sustainable Management and Protection of Mountain Areas (Ge.S.Di.Mont.), University of Milan, Via Morino 8, Edolo, 25048, Brescia, Italy
}

\section{ARTICLE INFO}

\section{Article history:}

Received 24 February 2021

Received in revised form 15 April 2021

Accepted 4 May 2021

Available online $\mathrm{xxx}$

Editor: José Virgílio Cruz

\section{Keywords}

Urban greenspaces

Nature-based solutions

Stormwater control measures

Unsaturated hydraulic conductivity

Fractional vegetation cover

Compacted soils

Soil rehabilitation

\begin{abstract}
A B S T R A C T
Climate change (higher frequency and intensity of precipitation events) and land use change (urbanization reducing soil drainage capacity) are increasingly causing stormwater problems globally, especially in cities. Nature-based solutions such as urban greenspace rehabilitation programs are gaining considerable attention for restoring soil retention capacity and protecting cities against increasing flood risk. However, a better understanding of how effective such measures are in practice is needed to enable and promote their adoption across urban settings. To this end, in this study, we assess the effect of soil rehabilitation measures in terms of soil compaction, vegetation cover and unsaturated hydraulic conductivity by analysing the results of an infiltration measurement campaign conducted across a wide range of real-world greenspaces (from recently rehabilitated, to poorly maintained, down to highly degraded) in the Italian city of Milan, one of the most urbanized areas in Europe.Our results show that the unsaturated hydraulic conductivity varies significantly across the examined greenspaces, due to differences in time from rehabilitation, soil compaction and vegetation cover. Specifically, we find that the highest unsaturated hydraulic conductivity is obtained after approximately 5 years since implementation of soil rehabilitation measures, which can be explained by the time needed (i) by the introduced vegetation to develop root systems, and (ii) by the soil matrix to develop a coherent structure that allows stable connections between pores and thus the strengthening of preferential water pathways. Finally, our study shows that, in absence of soil and vegetation maintenance, unsaturated hydraulic conductivity may decrease rapidly after about 9-12 years.These findings provide useful information for supporting the planning of nature-based solutions in practice, which will become increasingly important to protect our cities from climate change impacts and widespread urbanization going forwards.
\end{abstract}

\section{Introduction}

The rapid and widespread urbanization of agricultural and natural environments is severely impacting the retention capacity of soils, with detrimental hydrological effects globally (Seto et al., 2013; Chen et al., 2014; Masseroni et al., 2017; Recanatesi et al., 2017; Li et al., 2018; Salerno et al., 2018; Schoener, 2018). In addition to the initial disturbance resulting from the conversion into urban land uses, such abrupt transformations can adversely influence physical, chemical and biological properties of the soils, affecting their infiltration capacity and undermining their role in flood prevention and ecosystem services provision (Zhang et al., 2015; Kvočka et al., 2016; Yao et al., 2017; Akter et al., 2018). Soil compaction resulting from urbanization can alter soils' aggregate arrangement and porosity matrix (Yang and Zhang, 2008; Chen et al., 2014), and urban develop-

\footnotetext{
* Corresponding authors at: Department of Agricultural and Environmental Sciences, University of Milan, Via Celoria 2, 20133 Milan, Italy.

E-mail addresses: andrea.galli1@unimi.it (A. Galli); daniele.masseroni@unimi.it (D. Masseroni)
}

ments can lead to drastic changes in soil hydraulic characteristics, with significant reductions in terms of drainage capacity (Gregory et al., 2006). In turn, implications may include impaired water quality, higher runoff volumes, reduced runoff lag time and groundwater recharge, potentially leading to increases in flood risk.

While analyses under controlled conditions are common, real-world soil infiltration capacities are still largely unexplored in urban areas, which is a bottleneck towards providing effective decision support. Results of laboratory tests/experiments on compacted soil samples of different texture demonstrate that the surface layer of the soil can lose up to $82 \%$ of its saturated hydraulic conductivity due to aggregate break-downs and macropore losses (Zhang et al., 2006). This highlights how soil compaction could have severe repercussions on infiltration capacity especially for soils located in urban settings, where the levels of compaction are worsened by the movement of vehicles and pedestrian traffic. However, information on the infiltration capacity of urban soils under uncontrolled conditions is limited, and measurement campaigns for detecting the real drainage aptitude of urban soils under different levels of natural/artificial compaction are needed to better understand the spatio-temporal variability of soil hydraulic properties and therefore guide rehabilitation practices in cities. 
In developed countries, urban greenspace rehabilitation measures and programs are gaining considerable attention to restore soil retention and drainage capacity (Chen et al., 2014). In highly urbanized areas, traditional stormwater control measures, such as the construction of detention basins, stormwater tanks, by-pass and flood diversion channels, are increasingly proving unfeasible due to a lack of open spaces, as well as insufficient at mitigating effectively the higher runoff volumes linked with climate change-driven more intense rainfall events (Mahmood et al., 2017; Jiang et al., 2018; Mahmoud and Gan, 2018; Zhou et al., 2018). Moreover, concerns are raising as, by accumulating and redirecting large volumes of runoff, traditional stormwater control measures can induce hydrological disturbance and contribute to the spread of pollutants in urban and peri-urban ecosystems (Roy et al., 2008). Instead, recent guidelines are encouraging administrations and authorities to invest in the hydraulic-hydrologic invariance development of urban areas (Pappalardo et al., 2017; Masseroni et al., 2019), which involves safeguarding urban greenspaces through soft-path solutions exploiting natural retention and infiltration capacities of the soils that are already part of the urban tissue (Pyke et al., 2011). Essentially, this entails a shift in terms of the main purpose of urban greenspaces from an aesthetic and ornamental role towards a stormwater prevention function (Mullaney et al., 2015).

However, a deeper understanding of the role of vegetation cover is needed to further justify and promote the adoption of nature-based stormwater control measures across urban settings. The use of vegetation on urban soils is expected to play a key role in improving soil permeability (Colaninno et al., 2019), and planting urban trees can help to reduce runoff peaks by enhancing the rainfall interception (Xiao and McPherson, 2016; Nytch et al., 2019) and the infiltration at the base of the trunk where stemflow fluxes were funnelled (Schooling and Carlyle-Moses, 2015; Van Stan and Allen, 2020). For example, Rahman et al. (2019) observed that, in natural environments, root systems allow the development of preferential drainage channels in the soil resulting in an increase in infiltration rate and deep percolation. However, the impact of vegetation cover on the infiltration capacity of soils in urban contexts has not yet been investigated in detail and targeted studies to understand its implications on hydrological factors are needed.

Therefore, in this work, we investigate how (and over which timescales) soil rehabilitation interventions affect the infiltration capacity of soils that are disturbed by urban developments, including how these effects may be modulated by soil compaction levels and the presence of vegetation, using a real-world example as a case study. Specifically, we perform in-situ infiltration measurements on greenspaces within the urban tissue of the Italian city of Milan (with about 1.3 million of resident people) and assess the effects of soil compaction, vegetation cover, and their interaction, on unsaturated hydraulic conductiv- ity, gaining important insights for supporting soil rehabilitation plans across urban areas.

\section{Materials and methods}

\subsection{Study domain}

The study domain we focus on in our analysis comprises 49 greenspaces (specifically, street-level greenspaces such as green sidewalks, roundabouts and median strips), located within the urban tissue of the city of Milan, Italy.

According to the Köppen-Geiger classification (Geiger, 1961), the study domain has a humid-subtropical climate, with a mean annual air temperature of about $15{ }^{\circ} \mathrm{C}$, an annual rainfall total of about $1000 \mathrm{~mm}$ and average daily rainfall intensity of about $10 \mathrm{~mm} / \mathrm{h}$, evaluated over the period from 1899 to 2016 (Ranzi et al., 2021). Recent studies carried out by the Meteorological Observatory of Milan Cathedral as part of the ClimaMi project (www.progettoclimami.it) showed that climate change is already heavily affecting temperature and rainfall patterns within the study area. Specifically, since 1980, mean temperatures and average daily rainfall intensity have increased by approximately $1.5{ }^{\circ} \mathrm{C}$ and $14 \%$, respectively, making the city of Milan prone to frequent heat waves and damaging flood events (Brunetti et al., 2000, 2004; Persiano et al., 2020). Notably, based on historical data, while 2 flood events per year were observed on average over the period 1976-2017, flood frequency has increased up to 3 events per year in this area over the last fifteen years (Masseroni et al., 2017).

Infiltration measurements were carried out across a sub-district of the municipality of Milan, within a radius of about $3.5 \mathrm{~km}$ around the Cathedral (city centre). This is the most ancient and urbanized area of the city, with about $85 \%$ of impervious surfaces. Despite this sub-district is not usually the most affected by flooding, it represents a suitable pilot area, as the ratio between impervious surfaces, buildings, streets, and urban greenspaces is representative of the urban tissue of the entire city.

\subsection{Characteristics of the analysed urban greenspaces}

The soils characterising the examined greenspaces had different levels of vegetation cover, soil compaction, and state of maintenance, as shown in Fig. 1. In some cases, urban greenspaces were improperly used as parking lots and showed heavily compacted soils and no vegetation (Fig. 1a). In others, a lack of maintenance had led to a slow degradation of soils and a very scattered presence of vegetation (Fig. 1b). Instead, other greenspaces showed rehabilitated soil (Fig. 1c). In fact, in 2009, the Department of Green Spaces, Agriculture and Urban Design of the municipality of Milan (here in the follow DeGreSpA) launched a rehabilitation plan to avoid the progressive degradation of urban greenspaces consisting in the application of targeted operations, practices, and treatments to protect and conserve urban soils and en-
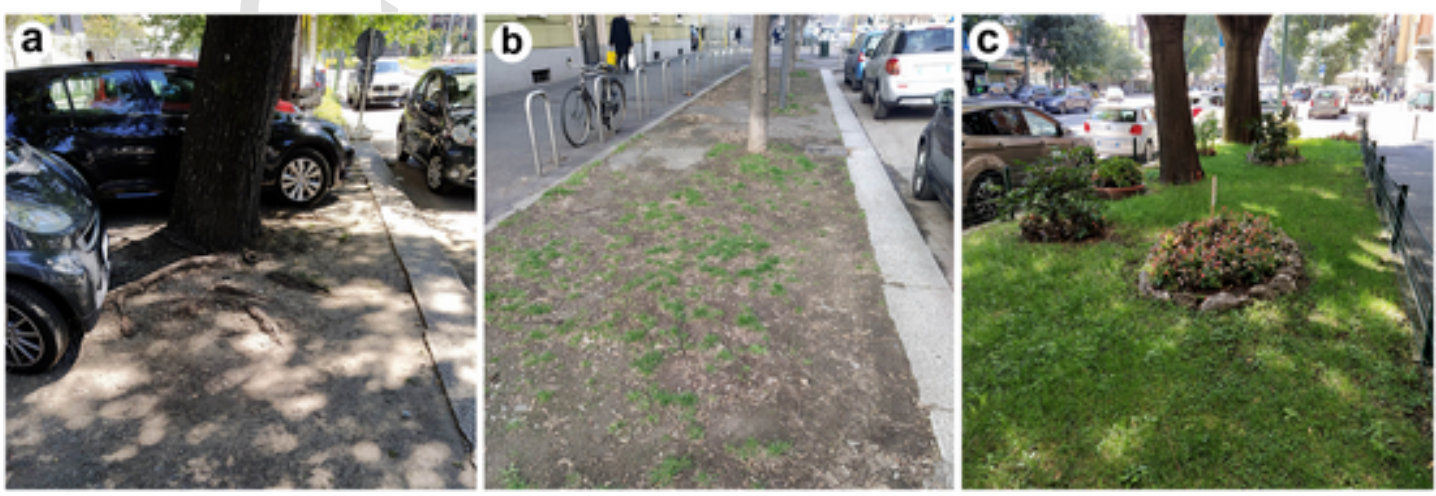

Fig. 1. Variety of urban greenspaces examined: (a) highly degraded soil, (b) poorly maintained soil, (c) rehabilitated soil. 
hance both their ornamental and hydraulic functions, the latter specifically connected to the improvement of infiltration capacity. Despite not always following a specific protocol, soil rehabilitation mainly consisted in (i) carrying out a surface soil tillage (from 8 to $15 \mathrm{~cm}$ of depth), (ii) laying a new surface layer $(10-15 \mathrm{~cm})$ of fertile topsoil (organic matter $>4 \%$ ), (iii) sowing grass species easily available on the market such as Festuca arundinacea, Poa pratensis, Lolium perenne, Agrostis stolonifera and lastly (iv) planting, where feasible, shrubs species such as Berberis vulgaris, Euonymus latifolius, Pittosporum tobira, Arbustus menziesii, Buxus sempervirens. Usually, crop water requirements were satisfied by fixed time-based drip-irrigation systems, whereas low fences were built around rehabilitated greenspaces to prevent compaction and soil detriment caused by vehicle and pedestrian passage. Lastly, grass cutting and shrub pruning were carried out sporadically without specific scheduling.

\subsection{Measurement campaigns}

Measurement campaigns involved assessments of unsaturated hydraulic conductivity, soil moisture, soil compaction, and vegetation cover, as detailed below.

Soil infiltration capacities were determined directly in-situ by measuring the unsaturated hydraulic conductivity of the soil $(K)$ using a Mini-Disk Infiltrometer (MDI) (METER Group Inc., 2020). The MDI is a highly portable and inexpensive tension infiltrometer developed by METER Group Inc. USA (Fig. 2). Infiltration measurements were performed following the protocols described in the MDI user manual (freely accessible at www.metergroup.com/environment/products/ mini-disk-infiltrometer). In particular, the MDI was used to measure cumulative infiltration with a pressure head (suction) of $-2 \mathrm{~cm}$, which is adequate for most soils - as reported in the MDI manual. Before placing the MDI, the soil surface was cleaned and delicately levelled using a

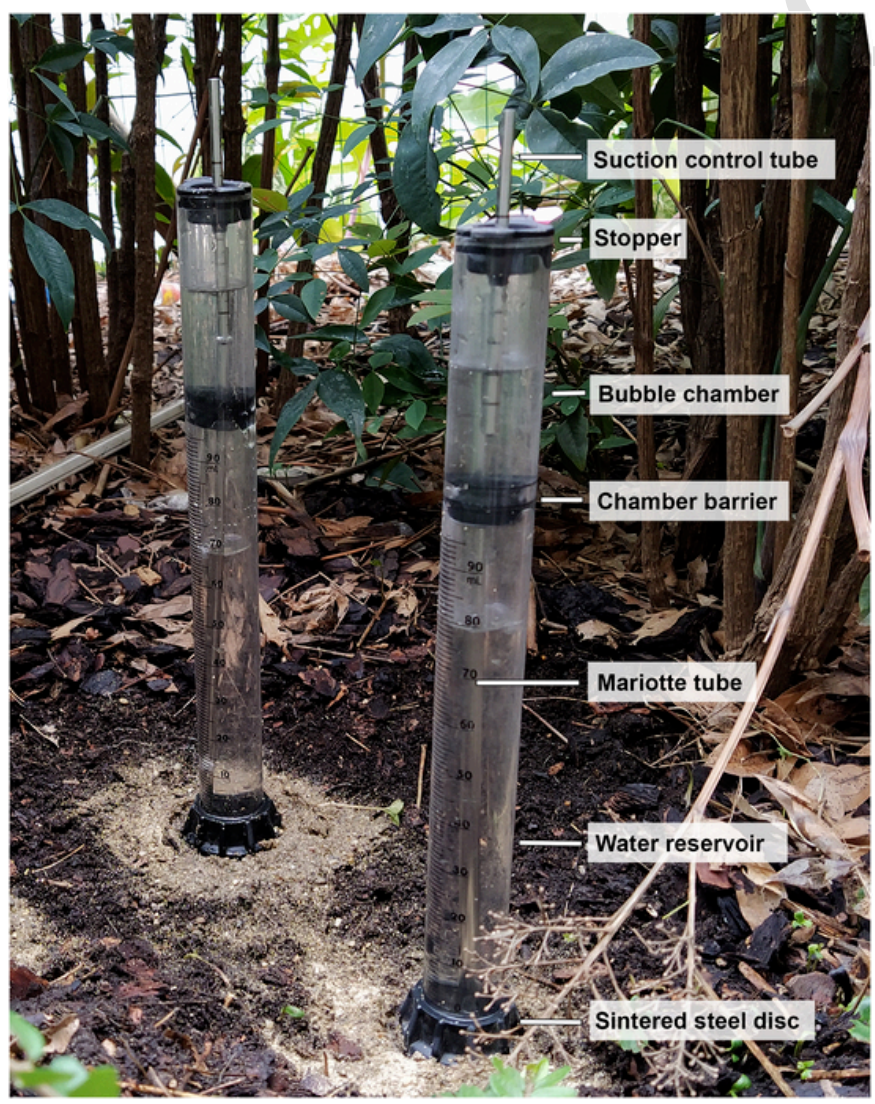

trowel and scissors to avoid the overturning of the device during measurements, as well as to allow a perfect adherence between the sintered filter of the instrument and the soil surface. To ensure the contact between the sintered disk and soil surface, a thin layer of sand (about $0.5 \mathrm{~cm}$ thick) was added, as suggested in the manual. The variation of water level inside the minidisk water reservoir was manually recorded at regular time intervals of $30 \mathrm{~s}$, for a total of about $7 \mathrm{~min}$ for each test. At each measurement point, 3 to 9 repetitions were carried out (depending on the variability of the recorded measurements in each trial), for a total of 192 infiltration measurements performed over the period February-October 2020.

The unsaturated hydraulic conductivity was derived by combining the obtained cumulative infiltration measures with knowledge of van Genuchten's soil parameters (van Genuchten, 1980) using Zhang's method (Zhang, 1997).

The cumulated infiltration, I ( $\mathrm{mm}$ ) versus time, $\mathrm{t}(\mathrm{s})$ data were fitted by Eq. (1).

$I=C_{1} t^{\frac{1}{2}}+C_{2} t$

where $C_{1}\left(\mathrm{~m} / \mathrm{s}^{1 / 2}\right)$ and $C_{2}(\mathrm{~m} / \mathrm{s})$ are the two calibration parameters mainly related to soil sorptivity and unsaturated hydraulic conductivity.

The value of $K(\mathrm{~cm} / \mathrm{s})$ was calculated using Eq. (2).

$K=\frac{C_{2}}{A_{2}}$

where $A_{2}$ is a parameter depending on (i) van Genuchten parameters, (ii) soil texture, (iii) suction level and (iv) infiltrometer radius according with Eqs. (3) or (4).

$A_{2}=\frac{11.65\left(n^{0.1}-1\right) \exp \left[2.92(n-1.9) \alpha h_{0}\right]}{\left(\alpha r_{0)}{ }^{0.91}\right.} n$

$\geq 1.9$

$A_{2}=\frac{11.65\left(n^{0.1}-1\right) \exp \left[7.5(n-1.9) \alpha h_{0}\right]}{\left(\alpha r_{0)}{ }^{0.91}\right.} n<1.9$

where $r_{0}$ is the infiltrometer's radius (equal to $2.25 \mathrm{~cm}$ ), $n$ and $\alpha$ are the van Genuchten retention parameters depending on soil texture as reported in Table 1 , and $h_{0}$ is the suction level (set to $-2 \mathrm{~cm}$ ).

For determining van Genuchten's parameters ( $n$ and $\alpha$ ), soil texture was assessed by collecting soil samples at each measurement point at a depth ranging from 0 to $15 \mathrm{~cm}$, which represents the soil layer involved in the prevention of surface and hypodermic runoff (Pitt et al., 1999; Rahman et al., 2019). Soil samples were processed in the Soil Analysis Lab of the Department of Agricultural and Environmental Sciences

Table 1

Van Genuchten's parameters $\alpha$ and $\mathrm{n}$ in function of soil texture (based on MDI user manual).

\begin{tabular}{lll}
\hline Soil texture & $\alpha$ & $\mathrm{n}$ \\
\hline Sand & 0.145 & 2.68 \\
Loamy sand & 0.124 & 2.28 \\
Sandy loam & 0.075 & 1.89 \\
Loam & 0.036 & 1.56 \\
Silt & 0.016 & 1.37 \\
Silt loam & 0.020 & 1.41 \\
Sandy clay loam & 0.059 & 1.48 \\
Clay loam & 0.019 & 1.31 \\
Silty clay loam & 0.010 & 1.23 \\
Sandy clay & 0.027 & 1.23 \\
Silty clay & 0.005 & 1.09 \\
Clay & 0.008 & 1.09 \\
\hline
\end{tabular}

Fig. 2. Example of in-situ application of a Mini-Disk Infiltrometer and its components. 
(DiSAA) of the University of Milan and soil texture was determined using the pipette method (Gee and Bauder, 1986; Indorante et al., 1990; Moshrefi, 1993), following international standards ISO 11277 (2009).

Soil moisture was measured using a ThetaProbe ML3 sensor (Delta-T Devices, UK, 2017), by inserting the probe into the ground in five different points and averaging the readings for each site. Infiltration measurements were only carried out where soil moisture was below $0.35 \mathrm{~m}^{3} \mathrm{~m}^{-3}$, in order to avoid a strong influence of initial soil moisture conditions on unsaturated hydraulic conductivity results (Zhou et al., 2008; Bhave and Sreeja, 2013; Matula et al., 2015).

Soil compaction was measured through a hand-held cone penetrometer with a metal conical tip of $4.12 \mathrm{~cm}^{2}$, which provides an estimate of the Cone Index (CI) - that can be read directly on the instrument's dial as an indicator of soil compaction (Carrara et al., 2007; Veronesi et al., 2012; Agustín-Alesso et al., 2017). The cone was inserted up to $15 \mathrm{~cm}$ of depth in five different points and the average of readings was considered for the following analyses.

Three digital pictures took orthogonally over the ground at a distance of about $1 \mathrm{~m}$ were used for assessing the fractional vegetation cover at each site (Coy et al., 2016). A white reference target of $4 \mathrm{~cm}^{2}$ was inserted in the picture during the post-elaboration of the image to calculate the vegetation cover area. The Otsu (1979) threshold method allowed separating vegetation from other objects in the image, including bare soil (Fig. 3). The fractional vegetation cover was obtained as the ratio between the vegetation cover area and the ground surface photographed by the camera (approximately $1.75 \mathrm{~m}^{2}$ ).

\subsection{Data analysis}

Measurements of unsaturated hydraulic conductivity were grouped into different classes of soil rehabilitation, soil compaction and vegetation cover to investigate the effects of these factors on soil infiltration capacity of urban greenspaces. Specifically, four classes of soil rehabilitation, soil compaction and vegetation cover were identified, as reported in Table 2. These were identified together with DeGreSpA technicians by combining their field experience with the requirement of having a minimum of 20 infiltration measurements in each class, to guarantee statistical significance of the data samples. Values of $K$ in each class were analysed by using boxplots (which show five statistics: minimum, maximum, the sample median, the first and third quartiles, plus outliers plotted as individual points). The mean value of $K$ in each class was calculated excluding outliers. To investigate the difference between classes, one-way ANOVA on ranks with the non-parametric Kruskal-Wallis test (Kruskal and Wallis, 1952) was applied. This type of test was already proposed in previous studies (Rahman et al., 2019 ) to assess the influence of measured meteorological, edaphic and tree morphological data on soil cumulative infiltration capability of soils and therefore we considered it appropriate also for the goals of our case study. In all cases, the differences were considered to be significant when $p$-values were below 0.05 .

\section{Results and discussion}

\subsection{Soil texture of the examined urban greenspaces}

The soil texture of the examined urban greenspaces was found to be homogenous across the study area, with no significant spatial pattern (results of the soil analysis are reported on the USDA texture diagram in Fig. 4). Overall, the soils were sandy loam (for about $75 \%$ of samples), followed by loamy sand (15\% of samples) and loam (10\%).

From a visual inspection, soil samples presented scarce organic matter and a clear destructured nature. Usually, urban soils include macro-aggregates, rock, or crushed paving material, already from surface layers (Vodyanitskii, 2015), whereas our samples (taken from 0 to $15 \mathrm{~cm}$ of depth) mostly looked like a miscellaneous of fine-grained soils, both in rehabilitated and degraded greenspaces. The percentage of gravel (i.e. of particles larger than $2 \mathrm{~mm}$ in size) was less than $5 \%$ in every sample.

\subsection{Spatial variability of unsaturated hydraulic conductivity across the urban greenspaces}

Results of the measurement campaigns showed high variability in unsaturated hydraulic conductivity across examined urban greenspaces. Overall, observed values ranged from a minimum of $0.28 \mathrm{~mm} / \mathrm{h}$ to a maximum of $131.91 \mathrm{~mm} / \mathrm{h}$, with a mean of $20.06 \mathrm{~mm} / \mathrm{h}$ (Fig. 5).

Infiltration measurements were carried out in six different parts of the city and Fig. 5 shows the spatial variability of $K$ values. Despite there is not a clear pattern of the unsaturated hydraulic conductivity on the study domain, measurements in the eastern part of the city (mainly in Via Bronzetti, Via Cadore and Via Filippetti) are characterized by a reduced variability of $K$ values, i.e. the difference between third and first quartile of each group of measurements is found to be below $10 \mathrm{~mm} / \mathrm{h}$, whereas in the western part of the city (i.e. Via Washington, Via Elba, Via Procida, Via Buonarroti and Via Ravizza, except Via Ricciarelli) the variability is important, and above the $25 \mathrm{~mm} / \mathrm{h}$. Moreover, the unsaturated hydraulic conductivity in the eastern part of the study domain is on average is 2 times lower compared to the western one. The explanation of these results is in good agreement with the effects of the envisaged rehabilitation actions performed by DeGreSpa in the last decade. In particular, urban greenspaces in the western parts were in general rehabilitated more recently than the eastern ones (about from the year 2018), and they are still characterized by high variability of vegetation cover and an incoherent structure of soils
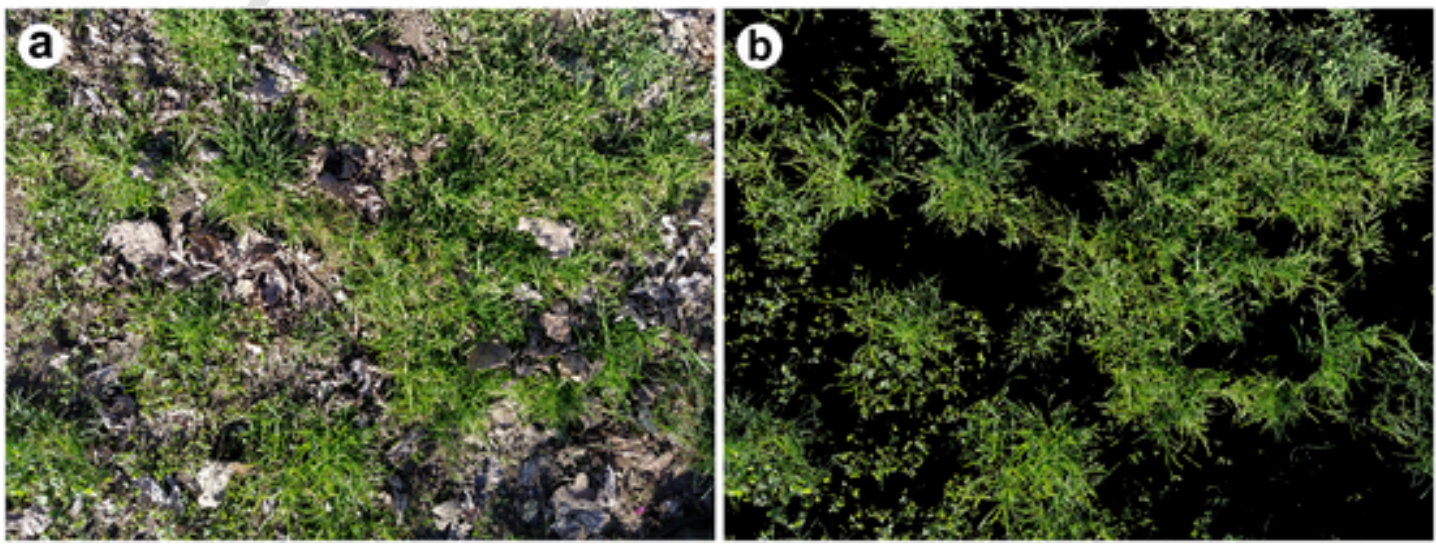

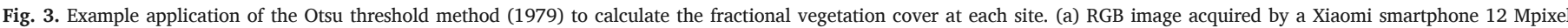
$(3000 \times 4000)$ camera. (b) Grass cover after application of the Otsu method. 
Table 2

Classification of examined soils based on rehabilitation period, compaction level and vegetation cover.

\begin{tabular}{|c|c|c|c|c|}
\hline Factor & Variable & Class & Code & $\begin{array}{l}\text { Number of } \\
\text { infiltration } \\
\text { measurements }\end{array}$ \\
\hline \multirow[t]{4}{*}{ Rehabilitation period } & Year & $\begin{array}{l}\text { Not } \\
\text { rehabilitated }\end{array}$ & NR & 45 \\
\hline & & $\begin{array}{l}\text { Rehabilitated } \\
\text { from year } \\
2009 \text { to } \\
2012\end{array}$ & R09-12 & 51 \\
\hline & & $\begin{array}{l}\text { Rehabilitated } \\
\text { from year } \\
2013 \text { to } \\
2016\end{array}$ & R13-16 & 48 \\
\hline & & $\begin{array}{l}\text { Rehabilitated } \\
\text { from year } \\
2017 \text { to } \\
2020\end{array}$ & R17-20 & 48 \\
\hline \multirow[t]{4}{*}{ Soil compaction } & $\begin{array}{l}\text { Cone } \\
\text { index } \\
(\mathrm{MPa})\end{array}$ & $<0.4$ & $\mathrm{C} 1$ & 64 \\
\hline & & $0.4-0.8$ & $\mathrm{C} 2$ & 39 \\
\hline & & $0.8-1.2$ & C3 & 59 \\
\hline & & $>1.2$ & $\mathrm{C} 4$ & 30 \\
\hline \multirow[t]{4}{*}{$\begin{array}{l}\text { Fractional vegetation } \\
\text { cover }\end{array}$} & $\begin{array}{l}\text { Percentage } \\
(\%)\end{array}$ & $<15$ & V1 & 85 \\
\hline & & $15-50$ & V2 & 36 \\
\hline & & $50-80$ & V3 & 21 \\
\hline & & $>80$ & V4 & 50 \\
\hline
\end{tabular}

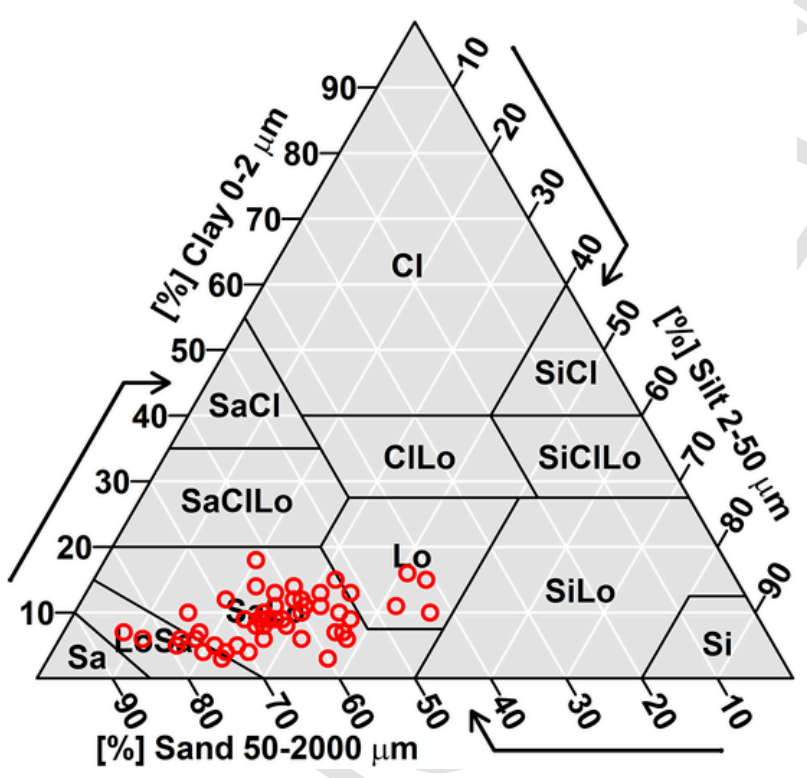

Fig. 4. Characteristics of examined soil samples (in red) within the USDA soil texture diagram. (For interpretation of the references to color in this figure legend, the reader is referred to the web version of this article.)

which makes much variable unsaturated hydraulic conductivity in the measurement points. On the contrary, in the eastern part of the study domain, the soils were rehabilitated before the year 2015 on average, and they are characterized by a general slow degradation of soils and a scattered presence of vegetation which leads to low but uniform values of $K$.

\subsection{Effect of soil rehabilitation on unsaturated hydraulic conductivity}

Firstly, considering the classification of observed $K$ values into two soil macro-classes "Not-Rehabilitated (NR) and "Rehabilitated" (R), the latter regardless of the year of the intervention, the effect of rehabilitation appears to be a significant increase in unsaturated hydraulic conductivity ( $p$-value $<0.01$ ). Specifically, an increase of about $70 \%$ ( $\mathrm{p}$-value $<0.02$ ) was found in the mean unsaturated hydraulic conductivity (i.e. from $9.42 \mathrm{~mm} / \mathrm{h}$ to $16.04 \mathrm{~mm} / \mathrm{h}$ ) when moving from $\mathrm{NR}$ to $\mathrm{R}$ soils (Fig. 6). In general, $75 \%$ of the $K$ values are below $15 \mathrm{~mm} / \mathrm{h}$ when considering the NR class, and below $27 \mathrm{~mm} / \mathrm{h}$ when looking at the $\mathrm{R}$ class.

Secondly, considering a more detailed classification of rehabilitated soils according to the year of rehabilitation, a gradual increase in unsaturated hydraulic conductivity was found from NR soils to soils rehabilitated between the years 2013 and 2016 (R13-16) (Fig. 7). In particular, the mean value of $K$ increases from $9.42 \mathrm{~mm} / \mathrm{h}$ to $20.18 \mathrm{~mm} / \mathrm{h}$ when moving from NR to R13-16 soils and then decreases again to $12.46 \mathrm{~mm} /$ $\mathrm{h}$ for the class R17-20. Significant differences between classes are confirmed by the $p$-values, which are below 0.04 . The maximum upper quartile of $K$ (i.e. $35 \mathrm{~mm} / \mathrm{h}$ ) is found for R13-16 soils, i.e. about four years before the last soil rehabilitation intervention carried out by DeGreSpA technicians on the urban greenspaces. The same increasing pattern of mean values of $K$ is found in the third quartile of each group, ranging from $15 \mathrm{~mm} / \mathrm{h}$ in NR to $35 \mathrm{~mm} / \mathrm{h}$ in R13-16 and then decreasing to $24 \mathrm{~mm} / \mathrm{h}$ in R17-20. Extreme values of $K$ (i.e. those below $5 \mathrm{~mm} /$ $\mathrm{h}$ or above $50 \mathrm{~mm} / \mathrm{h}$, according to the American Society of Civil Engineering and Soil Conservation Service standards) were found, on the one hand, where levels of soil compaction were very high and, on the other hand, where careful and effective soil rehabilitation measures had been carried out.

A parabolic-like behaviour is observed in the mean values of unsaturated hydraulic conductivity when considering them as a function of soil rehabilitation timing (Fig. 8). In particular, unsaturated hydraulic conductivity values increase until up to five years after the soil rehabilitation intervention, most likely as a consequence of an increase in pore connectivity, favoured by soil settling (i.e. natural compaction without the influence of anthropic factors such as vehicle movement or pedestrian traffic) and by the development of root systems of the introduced vegetation (Kodesova et al., 2011; Aschonitis et al., 2013). After five years, the unsaturated hydraulic conductivity tends to decrease, potentially as a consequence of the lack of soil and vegetation maintenance (e.g. soil tillage, addition of soil and organic amendments). Considering the best soil conditions found in our entire domain (i.e. a mean $K$ of about $20 \mathrm{~mm} / \mathrm{h}$ in the R13-16 class), the unsaturated hydraulic conductivity decreases below $10 \mathrm{~mm} / \mathrm{h}$ after approximately twelve years since rehabilitation. These results suggest that soil rehabilitation plans should be implemented over a period of nine to twelve years in order to avoid significant reductions in the infiltration capacity of the soil, with unsaturated hydraulic conductivity dropping below the initial value of about $12 \mathrm{~mm} / \mathrm{h}$ (i.e. after about 1 year since rehabilitation).

\subsection{Role of vegetation cover and soil compaction on unsaturated hydraulic conductivity}

The unsaturated hydraulic conductivity results to be significantly affected by vegetation cover ( $p$-value $<0.01$ ), as reported in Fig. 9a. The mean value of $K$ increases from $9.50 \mathrm{~mm} / \mathrm{h}$ to $33.55 \mathrm{~mm} / \mathrm{h}$ when moving from the class with fractional vegetation cover below $15 \%$ (V1) to that with vegetation cover above $80 \%$ (V4).

The increase observed in unsaturated hydraulic conductivity with vegetation cover confirms expectations, as a larger vegetation cover will be associated with the progressive development of root systems 


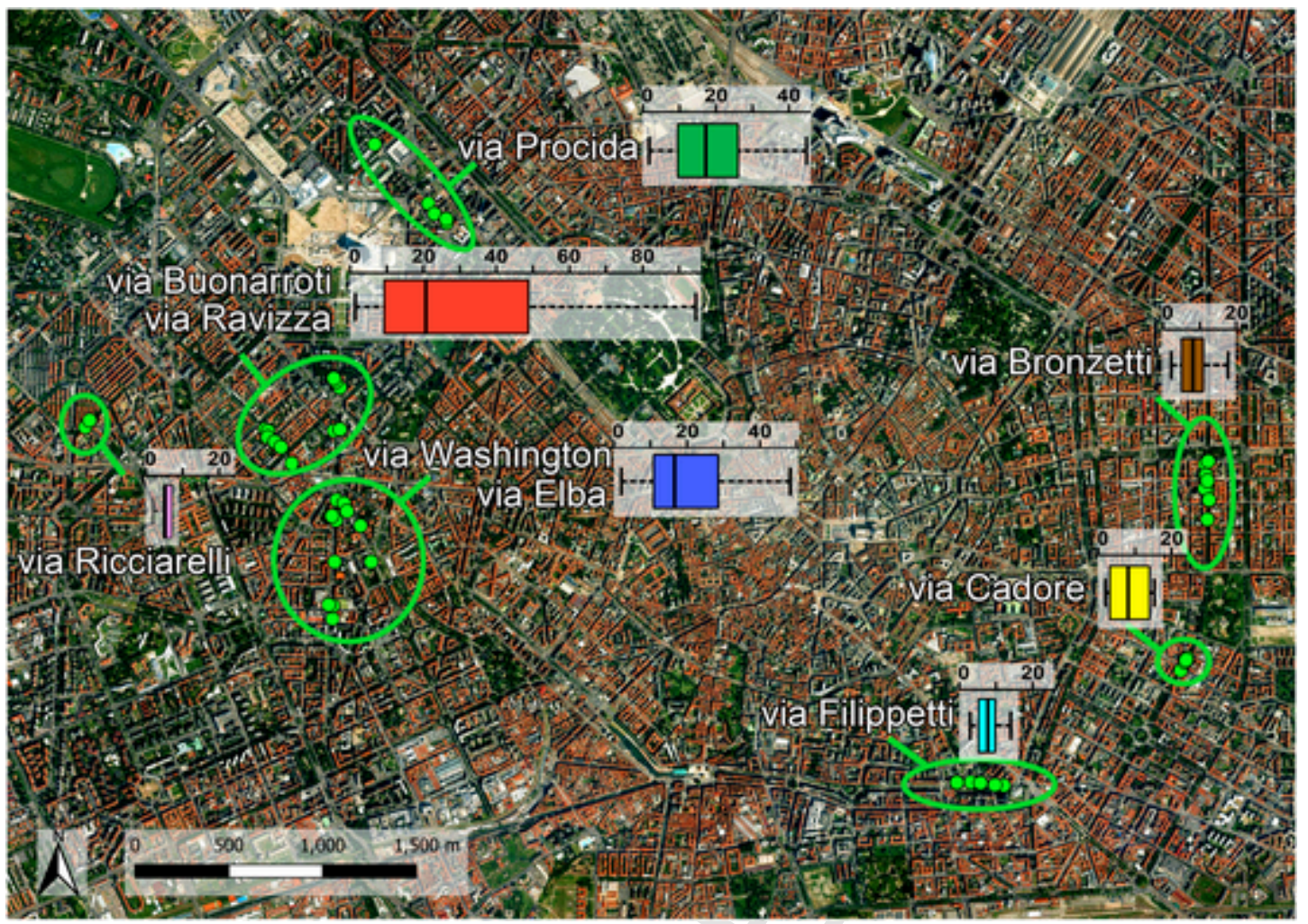

Fig. 5. Spatial variability of the unsaturated hydraulic conductivity within the study domain.

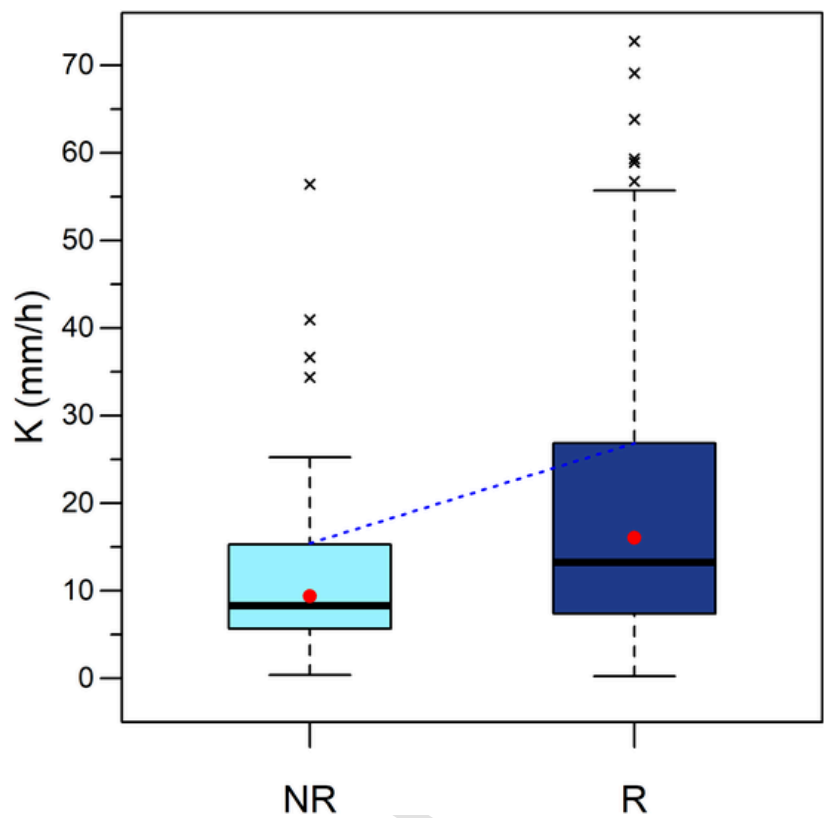

Fig. 6. Comparison of unsaturated hydraulic conductivity values for Not-Rehabilitated (NR) vs. Rehabilitated (R) soils. The mean for each class is represented as a red dot. (For interpretation of the references to color in this figure legend, the reader is referred to the web version of this article.)

(Schwartz et al., 2000; Chen et al., 2009; Nieber and Sidle, 2010; Wu et al., 2016; Gadi et al., 2017; Beck-Broichsitter et al., 2020). In particular, root systems work in near-surface and deep parts of the soil supporting the formation of macropores and the connectivity among large pores, thus favouring the flow of water across subsurface soil layers (Scanlan and Hinz, 2010; Kodesova et al., 2011; Beven and Germann, 2013; Chen et al., 2014; Wu et al., 2016). In Mu-

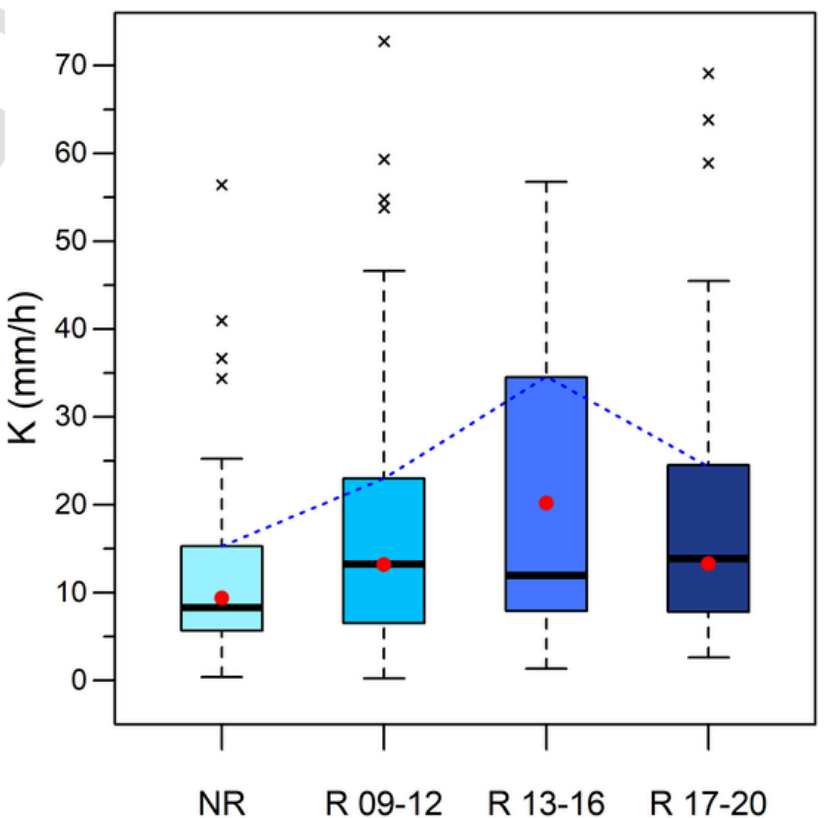

Fig. 7. Unsaturated hydraulic conductivity values classified based on the year of soil rehabilitation. The mean for each class is represented as a red dot. (For interpretation of the references to color in this figure legend, the reader is referred to the web version of this article.)

nich (Germany), Rahman et al. (2019) found that the presence of urban trees and shrubs of different species on urban soils can lead to an increase of $K$ from 2 to 5 times that obtained on bare or near-bare soils, which is in line with our findings (i.e. approximately a 3-fold increase in the mean value of $K$ from the first to the fourth vegetation cover class). The increase of $K$ with vegetation cover is also associated with an increase in the variability of $K$ in each vegetation cover class, as 


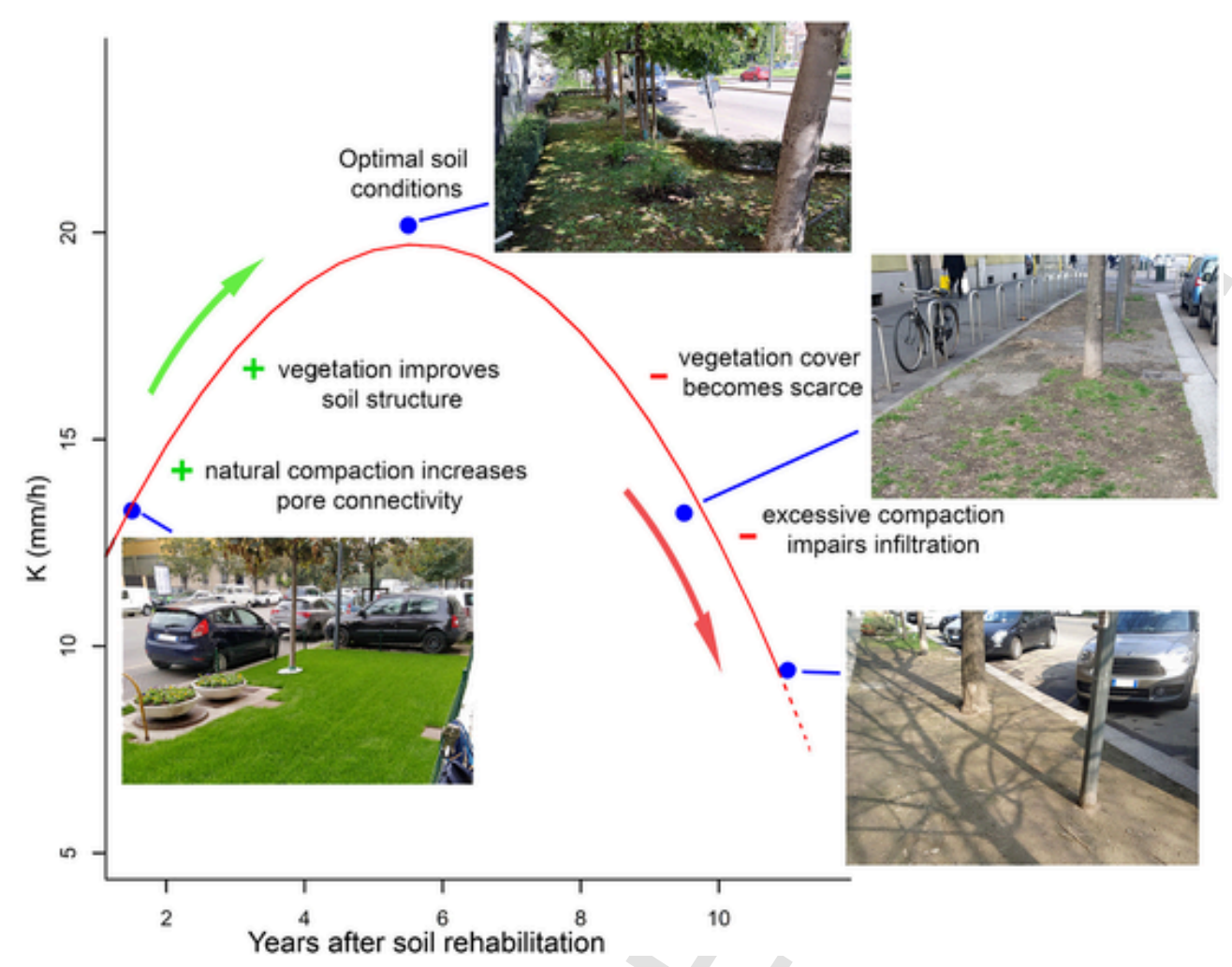

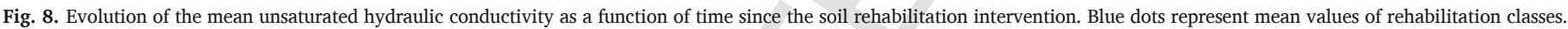
(For interpretation of the references to color in this figure legend, the reader is referred to the web version of this article.)
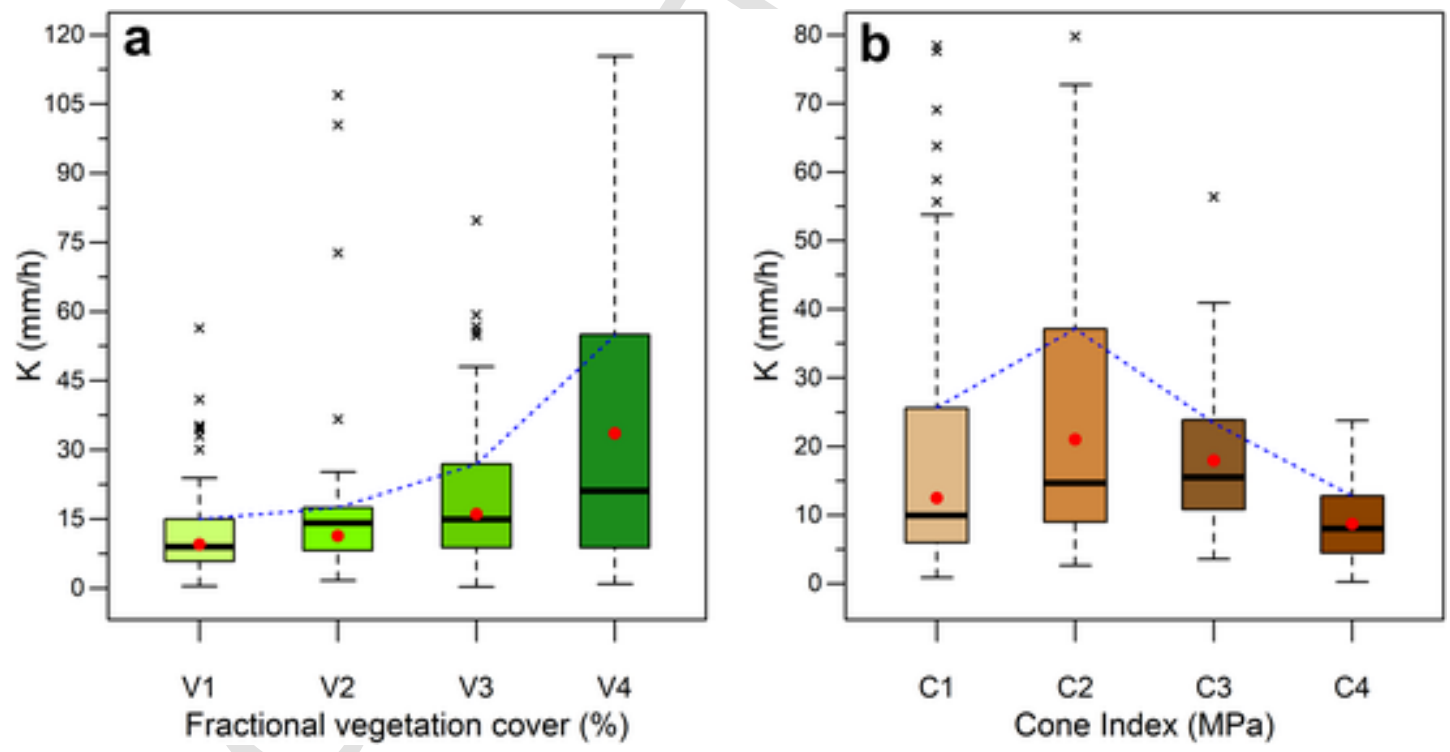

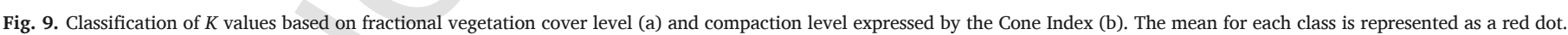
(For interpretation of the references to color in this figure legend, the reader is referred to the web version of this article.)

shown by the size of boxes presented in Fig. 9a. Such variability, which ranges from about $9 \mathrm{~mm} / \mathrm{h}$ (in classes V1 and V2) to about $46 \mathrm{~mm} / \mathrm{h}$ (in class V4), may be attributed to different interactions between root systems and the porosity of urban soils (Scanlan and Hinz, 2010; Kodesova et al., 2011). In our case, the shrub species found on top of grass cover on vegetated soils (e.g. Berberis vulgaris, Euonymus latifolius, Pittosporum tobira, Arbustus menziesii, Buxus sempervirens) are known to increase infiltration rates through their dense root system, as reported for example by $\mathrm{Wu}$ et al. (2017).
On the other hand, our results show that the unsaturated hydraulic conductivity is also significantly affected by soil compaction characterized by the Cone Index, as shown in Fig. 9b ( $p$-value $<0.01$ ).

The highest values in terms of mean and third quartile $(21.03 \mathrm{~mm} /$ $\mathrm{h}$ and $37.17 \mathrm{~mm} / \mathrm{h}$, respectively) are found within class $\mathrm{C} 2$, which is characterized by a medium level of soil compaction. In comparison, lower values of $K$ are found for both lower (below $0.4 \mathrm{MPa}, \mathrm{C} 1$ ) and higher compaction levels (above 0.8, C3). For example, the mean value of $K$ was $12.48 \mathrm{~mm} / \mathrm{h}$ for class $\mathrm{C} 1$ and $8.67 \mathrm{~mm} / \mathrm{h}$ for class C4. On the one hand, with regards to what we observe for high compaction level 
classes (C3 and C4), it seems that -on our domain- a Cone Index value of $0.8 \mathrm{MPa}$ acts as a threshold beyond which the urban soil loses much of its infiltration capacity. This can be attributed to the partial collapse of macropores and their physical connections when high levels of compaction are reached (Horton et al., 1994; Schäffer et al., 2007). In particular, only "relict pores" may remain in the soil (Bruand and Cousin, 1995), which are not connected in any way, and therefore prevent the easy flow of water through the soil, thus limiting infiltration processes (Richard et al., 2001). On the other hand, with regards to class C1, interestingly, we see that soils with low levels of compaction (i.e. below 0.4 MPa, found mainly in recently rehabilitated greenspaces), have approximately the same level of unsaturated hydraulic conductivity of compacted soils (e.g. close to those found for classes C3-C4). This can be explained as the soil matrix of recently rehabilitated soils may have not yet developed a coherent structure that allows the realization of stable connections between pores and thus the strengthening of preferential paths for water to flow through micropores (Strudley et al., 2008). Indeed, pore connectivity is considered one of the key features that regulate unsaturated flow across micropores (Guérif et al., 2001; Lipiec and Hatano, 2003; Lipiec et al., 2009). The result of this soil incoherence affects soil hydraulic proprieties, including unsaturated hydraulic conductivity, which, in our domain, decreases on average by $65 \%$ from class $\mathrm{C} 2$ to class $\mathrm{C} 1$.

\subsection{Effects of soil rehabilitation on vegetation cover and soil compaction}

By the previous results, we expect significant relationships when linking fractional vegetation cover and Cone Index values to soil rehabilitation levels. Fig. 10 shows that recently rehabilitated urban greenspaces are characterized by high levels of vegetation cover (on average above $70 \%$, Fig. 10a) and low levels of compaction (on average below 0.5 MPa, Fig. 10b), as a direct consequence of the rehabilitation process which entails the tillage of the soil surface layer and then the seeding of grass. In particular, the vegetation cover decreases from a mean value of $71 \%$ (in R17-20) to $6 \%$ (in NR) ( $p$-value $<0.01$ ), while the Cone Index increases from 0.45 MPa (in R17-20) to $1.34 \mathrm{MPa}$ (in $\mathrm{NR}$ ) (p-value $<0.05$ ). Intermediate values of fractional vegetation cover and soil compaction were found for classes R 09-12 and R 13-16. Specifically, in R09-12 the mean value of fractional vegetation cover is $35 \%$, which is very close to that found for class R 13-16, whereas the Cone Index is approximately $0.7 \mathrm{MPa}$ in R $09-12$ and $0.5 \mathrm{MPa}$ in R 13-16. These results corroborate the trends reported in Fig. 8. Specifically, the optimal soil conditions (i.e. where $K$ is maximum) were achieved

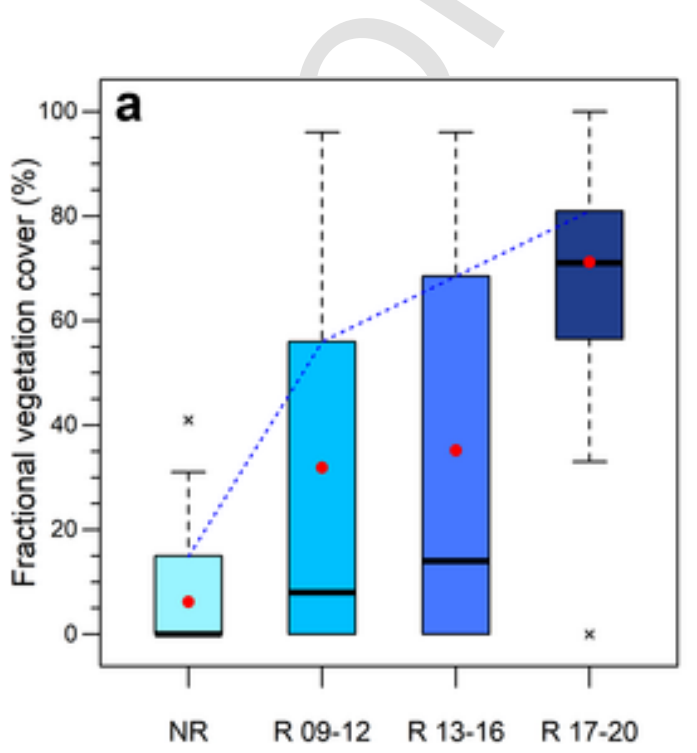

when a good balance between moderate soil compaction and vegetation cover occurred, i.e. after about five years for soil rehabilitation (class R13-16).

\section{Conclusions}

Urban greenspace rehabilitation programs are gaining considerable attention for restoring soil retention capacity and protecting against increasing flood risk linked with climate change and urbanization. However, a better understanding of how effective such measures are in practice is needed for decision support.

Our work, which analyses results from a measurement campaign conducted across a wide range of degraded vs. rehabilitated greenspaces in the Italian city of Milan, taken as a case study, shows that the infiltration capacity of urban soils can vary significantly due to differences in time from rehabilitation, soil compaction and vegetation cover.

Specifically, while, as expected, rehabilitated soils show higher conductivity than not re-qualified ones overall, further analysis indicates a parabolic-like behaviour of mean conductivity as a function of time since rehabilitation, with the best outcome in terms of conductivity levels obtained after approximately 5 years from rehabilitation.

We find that the reason why it is not the most recently rehabilitated ones to have the highest conductivity is that it takes time 1) for the introduced vegetation to develop root systems, and 2) for the soil matrix to develop a coherent structure that allows stable connections between pores and thus the strengthening of preferential paths for water to flow.

Finally, our study shows that, in absence of soil and vegetation maintenance, conductivity may decrease rapidly after about 9-12 years, which is useful information for planning nature-based solutions to stormwater problems in practice, which will become increasingly important to adapt to climate change impacts and rapid urbanization rates across areas.

\section{Uncited reference}

USDA, 1987

\section{CRediT authorship contribution statement}

Andrea Galli: Investigation, Validation, Data curation, Visualization, Writing - original draft. Cosimo Peruzzi: Investigation, Validation, Visualization, Writing - review \& editing. Ludovica Beltrame: Conceptualization, Investigation, Writing - review \& editing. Alessio Cislaghi: Methodology, Formal analysis, Data curation, Writing - review \& editing. Daniele Masseroni: Conceptualization, Methodol-

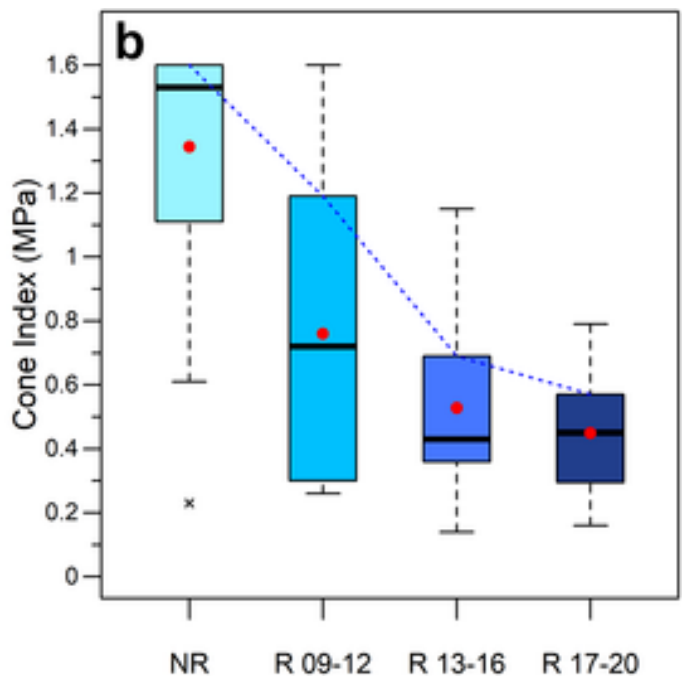

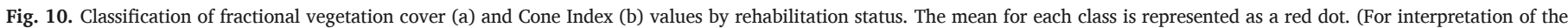
references to color in this figure legend, the reader is referred to the web version of this article.) 
ogy, Resources, Writing - review \& editing, Supervision, Project administration, Funding acquisition.

\section{Declaration of competing interest}

The authors declare that they have no known competing financial interests or personal relationships that could have appeared to influence the work reported in this paper.

\section{Acknowledgements}

This research was funded by Fondazione Cariplo in the context of two projects, Smart-Green (grant 2016-2070) and Monalisa (grant 2019-2084). The work was developed in collaboration with the professional association of agronomists of Milan, as well as the 'Area Verde, Agricoltura e Arredo Urbano' department of the municipality of the city. In particular, the authors are grateful to Dr. Massimilano Cannata and his team for their technical support. Special thanks also to Dr. Antonia Moreno and Dr. Paolo Sala, from the University of Milan, as well as to Dr. Paolo Fogliata, from the University of Udine, for their assistance in the analysis of soil texture and in measurement campaigns.

\section{References}

Agustín-Alesso, C.A., Carrizo, M.E., Del Carmen Imhoff, S., 2017. Mapping soil compaction using indicator kriging in Santa Fe province Argentina. Acta Agronomica 66 (1), 81-87. doi:10.15446/acag.v66n1.54775.

Akter, T., Quevauviller, P., Eisenreich, S.J., Vaes, G., 2018. Impacts of climate and land use changes on flood risk management for the Schijn River, Belgium. Environ. Sci. Pol. 89 (November 2017), 163-175. doi:10.1016/j.envsci.2018.07.002.

Aschonitis, V.G., Antonopoulos, V.Z., Lekakis, E.H., Litskas, V.D., Kotsopoulos, S.A., Karamouzis, D.N., 2013. Estimation of field capacity for aggregated soils using changes of the water retention curve under the effects of compaction. Eur. J. Soil Sci. 64 (5), 688-698.

Beck-Broichsitter, S., Gerke, H.H., Leue, M., von Jeetze, P.J., Horn, R., 2020. Anisotropy of unsaturated soil hydraulic properties of eroded Luvisol after conversion to hayfield comparing alfalfa and grass plots. Soil Tillage Res. 198 (April 2019), 104553. doi:10.1016/j.still.2019.104553.

Beven, K., Germann, P., 2013. Macropores and water flow in soils revisited. Water Resour. Res. 49 (6), 3071-3092. doi:10.1002/wrcr.20156.

Bhave, S., Sreeja, P., 2013. Influence of initial soil condition on infiltration characteristics determined using a disk infiltrometer. ISH J. Hydraulic Eng. 19 (3), 291-296. doi:10.1080/09715010.2013.808445.

Bruand, A., Cousin, I., 1995. Variation of textural porosity of a clay-loam soil during compaction. Eur. J. Soil Sci. 46 (3), 377-385. doi:10.1111/ j.1365-2389.1995.tb01334.x.

Brunetti, M., Buffoni, L., Maugeri, M., Nanni, T., 2000. Precipitation intensity trends in northern Italy. Int. J. Climatol. J. Roy. Meteorol. Soc. 20 (9), 1017-1031.

Brunetti, M., Buffoni, L., Mangianti, F., Maugeri, M., Nanni, T., 2004. Temperature, precipitation and extreme events during the last century in Italy. Glob. Planet. Chang. 40 (1-2), 141-149.

Carrara, M., Castrignanò, A., Comparetti, A., Febo, P., Orlando, S., 2007. Mapping of penetrometer resistance in relation to tractor traffic using multivariate geostatistics. Geoderma 142 (3-4), 294-307. doi:10.1016/j.geoderma.2007.08.020.

Chen, X., Zhang, Z., Chen, X., Shi, P., 2009. The impact of land use and land cover changes on soil moisture and hydraulic conductivity along the karst hillslopes of Southwest China. Environ. Earth Sci. 59 (4), 811-820. doi:10.1007/s12665-009-0077-6.

Chen, Y., Day, S.D., Wick, A.F., McGuire, K.J., 2014. Influence of urban land development and subsequent soil rehabilitation on soil aggregates, carbon, and hydraulic conductivity. Sci. Total Environ. 494-495, 329-336. doi:10.1016/ j.scitotenv.2014.06.099.

Colaninno, N., Hazem Mahmoud Eldesoky, A., Morello, E., 2019. Tree canopy cover estimation by means of remotely sensed data for large geographical areas: overview, available data, and proposal. In: XIII International Conference on Virtual City and Territory: "Challenges and Paradigms of the Contemporary city", 13. Centro de Política de Suelo y Valoraciones (CPSV), pp. 1-14.

Coy, A., Rankine, D., Taylor, M., Nielsen, D.C., Cohen, J., 2016. Increasing the accuracy and automation of fractional vegetation cover estimation from digital photographs. Remote Sens. 8 (7), 21-25. doi:10.3390/rs8070474.

Delta-T Devices, 2017. Theta probe soil moisture sensor type ML3.

Gadi, V.K., Tang, Y.R., Das, A., Monga, C., Garg, A., Berretta, C., Sahoo, L., 2017. Spatial and temporal variation of hydraulic conductivity and vegetation growth in green infrastructures using infiltrometer and visual technique. Catena 155, 20-29. doi:10.1016/j.catena.2017.02.024.

Gee, G.W., Bauder, J.W., 1986. Particle size analysis. In: Klute, A. (Ed.), Methods of Soil Analysis. Part 1. Physical and Mineralogical Methods. Agron. Monogr., 2nd ed. 9. ASA and SSSA, Madison, WI, pp. 383-411.

Geiger, R., 1961. Das Klima der bodennahen Luftschicht. Anzeiger für Schädlingskunde 34, 159. doi:10.1007/BF01876122.
Gregory, J.H., Dukes, M.D., Jones, P.H., Miller, G.L., 2006. Effect of urban soil compaction on infiltration rate. J. Soil Water Conserv. 61 (3), 117-124.

Guérif, J., Richard, G., Dürr, C., Machet, J.M., Recous, S., Roger-Estrade, J., 2001. A review of tillage effects on crop residue management, seedbed conditions and seedling establishment. Soil Tillage Res. 61 (1-2), 13-32. doi:10.1016/ S0167-1987(01)00187-8.

Horton, R., Ankeny, M.D., Allmaras, R.R., 1994. Effects of compaction on soil hydraulic properties. Dev. Agric. Eng. 11, 141-165.

Indorante, S. J., Follmer, L. R., Hammer, R. D., \& Koenig, P. G. (1990). 1990. Indorante. Particle-Size Analysis by a Modified Pipette Procedure.pdf, 54(10), 560-563.

ISO, H, 2009. Soil Quality-Determination of Particle Size Distribution (Mechanical Composition) in Mineral Soil-Method by Sieving and Sedimentation (HRN ISO 11277: 2009). Croatian Standards Institute, Zagreb.

Jiang, Y., Zevenbergen, C., Ma, Y., 2018. Urban pluvial flooding and stormwater management: a contemporary review of China's challenges and "sponge cities" strategy. Environ. Sci. Pol. 80 (June 2017), 132-143. doi:10.1016/ j.envsci.2017.11.016.

Kodesova, R., Jirku, V., Kodes, V., Muhlhanselova, M., Nikodem, A., Žigová, A., 2011. Soil structure and soil hydraulic properties of Haplic Luvisol used as arable land and grassland. Soil Tillage Res. 111 (2), 154-161. doi:10.1016/j.still.2010.09.007.

Kruskal, W.H., Wallis, W.A., 1952. Use of ranks in one-criterion variance analysis. J. Am. Stat. Assoc. 47 (260), 583-621.

Kvočka, D., Falconer, R.A., Bray, M., 2016. Flood hazard assessment for extreme flood events. Nat. Hazards 84 (3), 1569-1599. doi:10.1007/s11069-016-2501-z.

Li, C., Liu, M., Hu, Y., Shi, T., Qu, X., Walter, M.T., 2018. Effects of urbanization on direct runoff characteristics in urban functional zones. Sci. Total Environ. 643, 301-311. doi:10.1016/j.scitotenv.2018.06.211.

Lipiec, J., Hatano, R., 2003. Quantification of compaction effects on soil physical properties and crop growth. Geoderma 116 (1-2), 107-136. doi:10.1016/ S0016-7061(03)00097-1.

Lipiec, J., Wójciga, A., Horn, R., 2009. Hydraulic properties of soil aggregates as influenced by compaction. Soil Tillage Res. 103 (1), 170-177. doi:10.1016/ j.still.2008.10.021.

Mahmood, M.I., Elagib, N.A., Horn, F., Saad, S.A.G., 2017. Lessons learned from Khartoum flash flood impacts: an integrated assessment. Sci. Total Environ. 601-602, 1031-1045. doi:10.1016/j.scitotenv.2017.05.260.

Mahmoud, S.H., Gan, T.Y., 2018. Urbanization and climate change implications in flood risk management: developing an efficient decision support system for flood susceptibility mapping. Sci. Total Environ. 636, 152-167. doi:10.1016/ j.scitotenv.2018.04.282.

Masseroni, D., Cislaghi, A., Camici, S., Massari, C., Brocca, L., 2017. A reliable rainfall-runoff model for flood forecasting: review and application to a semi-urbanized watershed at high flood risk in Italy. Hydrol. Res. 48 (3), 726-740. doi:10.2166/ nh.2016.037.

Masseroni, D., Ercolani, G., Chiaradia, E.A., Gandolfi, C., 2019. A procedure for designing natural water retention measures in new development areas under hydraulic-hydrologic invariance constraints. Hydrol. Res. 50 (5), 1293-1308. doi:10.2166/nh.2019.018

Matula, S., Miháliková, M., Lufinková, J., Bátková, K., 2015. The role of the initial soil water content in the determination of unsaturated soil hydraulic conductivity using a tension infiltrometer. Plant Soil Environ. 62 (11), 515-521. doi:10.17221/527/ 2015-PSE.

METER Group, Inc. 2020, Minidisk Infiltrometer, User's Manual. www.metergroup.com/ environment/products/mini-disk-infiltrometer

Moshrefi, N., 1993. A new method of sampling soil suspension for particle-size analysis. Soil Sci. 155 (4), 245-248.

Mullaney, J., Lucke, T., Trueman, S.J., 2015. A review of benefits and challenges in growing street trees in paved urban environments. Landsc. Urban Plan. 134, 157-166. doi:10.1016/j.landurbplan.2014.10.013.

Nieber, J.L., Sidle, R.C., 2010. How do disconnected macropores in sloping soils facilitate preferential flow? Hydrol. Process. 24 (12), 1582-1594. doi:10.1002/hyp.7633.

Nytch, C.J., Meléndez-Ackerman, E.J., Pérez, M.E., Ortiz-Zayas, J.R., 2019. Rainfall interception by six urban trees in San Juan, Puerto Rico. Urban Ecosyst. 22 (1), 103-115. doi:10.1007/s11252-018-0768-4.

Otsu, N. (1979). A threshold selection method from gray-level histograms. IEEE Transact. Syst., Man Cybernetic, 9(1), 62-66.NRC. (2008). Urban Stormwater Management in the United States. Washington, DC:

Pappalardo, V., Campisano, A., Martinico, F., Modica, C., Barbarossa, L., 2017. A hydraulic invariance-based methodology for the implementation of storm-water release restrictions in urban land use master plans. Hydrol. Process. 31 (23), 4046-4055.

Persiano, S., Ferri, E., Antolini, G., Domeneghetti, A., Pavan, V., Castellarin, A., 2020. Changes in seasonality and magnitude of sub-daily rainfall extremes in Emilia-Romagna (Italy) and potential influence on regional rainfall frequency estimation. J. Hydrol. Reg. Stud. 32(July, 100751. doi:10.1016/j.ejrh.2020.100751.

Pitt, R., Lantrip, J., Harrison, R., Henry, C.L., Xue, D., 1999. Infiltration through Disturbed Urban Soils and Compost-Amended Soil Effects on Runoff Quality and Quantity. National Risk Management Research Laboratory, Washington.

C. PykeM.P. WarrenT. JohnsonJ. LaGro Jr.J. ScharfenbergP. Groth...E. MainAssessment of low impact development for managing stormwater with changing precipitation due to climate changeLandsc. Urban Plan.10322011166173

Rahman, M.A., Moser, A., Anderson, M., Zhang, C., Rötzer, T., Pauleit, S., 2019. Comparing the infiltration potentials of soils beneath the canopies of two contrasting urban tree species. Urban For. Urban Green. 38, 22-32.

Ranzi, R., Michailidi, E.M., Tomirotti, M., Crespi, A., Brunetti, M., Maugeri, M., 2021. A multi-century meteo-hydrological analysis for the Adda river basin (Central Alps). Part II: daily runoff (1845-2016) at different scales. Int. J. Climatol. 41 (1), 181-199. 
Recanatesi, F., Petroselli, A., Ripa, M.N., Leone, A., 2017. Assessment of stormwater runoff management practices and BMPs under soil sealing: a study case in a peri-urban watershed of the metropolitan area of Rome (Italy). J. Environ. Manag. 201, 6-18. doi:10.1016/j.jenvman.2017.06.024.

Richard, G., Cousin, I., Sillon, J.F., Bruand, A., Guérif, J., 2001. Effect of compaction on the porosity of a silty soil: influence on unsaturated hydraulic properties. Eur. J. Soil Sci. 52 (1), 49-58. doi:10.1046/j.1365-2389.2001.00357.x.

Roy, A.H., Wenger, S.J., Fletcher, T.D., Walsh, C.J., Ladson, A.R., Shuster, W.D., Brown, R.R., 2008. Impediments and solutions to sustainable, watershed-scale urban stormwater management: lessons from Australia and the United States. Environ. Manag. 42 (2), 344-359. doi:10.1007/s00267-008-9119-1.

Salerno, F., Viviano, G., Tartari, G., 2018. Urbanization and climate change impacts on surface water quality: enhancing the resilience by reducing impervious surfaces. Water Res. 144, 491-502. doi:10.1016/j.watres.2018.07.058.

Scanlan, C.A., Hinz, C., 2010, August. Insights into the processes and effects of root-induced changes to soil hydraulic properties. In: 2010 19th World Congress of Soil Science, Soil Solutions for a Changing World. pp. 1-6.

Schäffer, B., Stauber, M., Müller, R., Schulin, R., 2007. Changes in the macro-pore structure of restored soil caused by compaction beneath heavy agricultural machinery: a morphometric study. Eur. J. Soil Sci. 58 (5), 1062-1073. doi:10.1111/ j.1365-2389.2007.00886.x.

Schoener, G., 2018. Urban runoff in the U.S. southwest: importance of impervious surfaces for small-storm hydrology. J. Hydrol. Eng. 23 (2), 05017033. doi:10.1061/ (asce)he.1943-5584.0001610.

Schooling, J.T., Carlyle-Moses, D.E., 2015. The influence of rainfall depth class and deciduous tree traits on stemflow production in an urban park. Urban Ecosyst. 18, 1261-1284. doi:10.1007/s11252-015-0441-0.

Schwartz, R.C., Unger, P.W., Evett, S.R., 2000. Land use effects on soil hydraulic properties. In: ISTRO 2000 conference: proceedings of the 15th International Conference of the International Soil Tillage Research Organization, ISTRO-2000 June 2000/editor JE Morrison. Texas Agricultural Experiment Station, Temple, Texas.

Seto, K.C., Parnell, S., Elmqvist, T., 2013. A global outlook on urbanization. In: Urbanization, Biodiversity and Ecosystem Services: Challenges and Opportunities. Springer, Dordrecht, pp. 1-12.

Strudley, M. W., Green, T. R., \& Ascough II, J. C. (2008). Tillage effects on soil hydraulic properties in space and time: state of the science. Soil Tillage Res., 99(1), 4-48.

USDA, 1987. Soil mechanics level i. Module 3-USDA textural soil classification. In: Study Guide User Manual. Delta-T Devices, Ltd., Cambridge, United Kingdom.

van Genuchten, M.T., 1980. A closed-form equation for predicting the hydraulic conductivity of unsaturated soils. Soil Sci. Soc. Am. J. 44 (5), 892-898. doi:10.2136/ sssaj1980.03615995004400050002x.

Van Stan, J.T., Allen, S.T., 2020. What we know about stemflow's infiltration area. Front. For. Glob. Change 3, 61. doi:10.3389/ffgc.2020.00061.

Veronesi, F., Corstanje, R., Mayr, T., 2012. Mapping soil compaction in 3D with depth functions. Soil Tillage Res. 124, 111-118. doi:10.1016/j.still.2012.05.009.

Vodyanitskii, Y.N., 2015. Organic matter of urban soils: a review. Eurasian Soil Sci. 48 (8), 802-811.

Wu, G.L., Yang, Z., Cui, Z., Liu, Y., Fang, N.F., Shi, Z.H., 2016. Mixed artificial grasslands with more roots improved mine soil infiltration capacity. J. Hydrol. 535, 54-60. doi:10.1016/j.jhydrol.2016.01.059.

Wu, G.L., Liu, Y., Yang, Z., Cui, Z., Deng, L., Chang, X.F., Shi, Z.H., 2017. Root channels to indicate the increase in soil matrix water infiltration capacity of arid reclaimed mine soils. J. Hydrol. 546, 133-139. doi:10.1016/j.jhydrol.2016.12.047.

Xiao, Q., McPherson, E.G., 2016. Surface water storage capacity of twenty tree species in Davis, California. J. Environ. Qual. 45 (1), 188-198. doi:10.2134/jeq2015.02.0092.

Yang, J.L., Zhang, G.L., 2008. Loss of soil water capacity in urban areas and it's impacts on environment. Soils 40 (6), 992-996.

Yao, L., Chen, L., Wei, W., 2017. Exploring the linkage between urban flood risk and spatial patterns in small urbanized catchments of Beijing, China. Int. J. Environ. Res. Public Health 14 (3). doi:10.3390/ijerph14030239.

Zhang, R., 1997. Determination of soil sorptivity and hydraulic conductivity from the disk infiltrometer. Soil Sci. Soc. Am. J. 61 (4), 1024-1030. doi:10.2136/ sssaj1997.03615995006100040005x.

Zhang, S., Grip, H., Lövdahl, L., 2006. Effect of soil compaction on hydraulic properties of two loess soils in China. Soil Tillage Res. 90 (1-2), 117-125. doi:10.1016/ j.still.2005.08.012.

Zhang, L., Wang, J., Bai, Z., Lv, C., 2015. Effects of vegetation on runoff and soil erosion on reclaimed land in an opencast coal-mine dump in a loess area. Catena 128, 44-53. doi:10.1016/j.catena.2015.01.016

Zhou, X., Lin, H.S., White, E.A., 2008. Surface soil hydraulic properties in four soil series under different land uses and their temporal changes. Catena 73 (2), 180-188. doi:10.1016/j.catena.2007.09.009.

Zhou, Y., Lai, C., Wang, Z., Chen, X., Zeng, Z., Chen, J., Bai, X., 2018. Quantitative evaluation of the impact of climate change and human activity on runoff change in the Dongjiang River Basin, China. Water 10 (5), 571. 